\title{
POLITIK ISLAM DI INDONESIA PASCA KEMERDEKAAN HINGGA DEMOKRASI TERPIMPIN
}

\author{
Rif'at Husnul Ma'afi \\ Institut Studi Islam Darussalam, Jl. Raya Siman KM 6 Siman Ponorogo 6347| | \\ nabhanperdana09@gmail.com
}

\begin{abstract}
This article describes about the Islamic political development in Indonesia after its independence to the guided democracy. In the early days of its independence, there was a debate among Islamists and nationalists in formulating legislation until they agreed upon the first principle "Belief in one God". At the time of parliamentary democracy, many Islamic organizations established a political party and participated in the general election in 1955, including Masjumi, NU, PSII and Perti. At the time of the guided democracy, there were two groups of the Islamic party. The first group was Masjumi which viewed that the participation in the authoritarian political system as a deviation from Islamic teachings. The second group was the Muslim League (NU, PSII and Perti). They argued that participating in the guided democracy was a realistic and pragmatic attitude. The destruction of the Guided Democracy occurred after a mutiny by PKI's movement on September $30^{\text {th }}$, 1965. With the expiration of the Guided Democracy's period then ended the old order and changed into the new order under the Suharto's power. This resulted a change in Islamic politics in Indonesia.
\end{abstract}

Keywords: Islam, post-independence, guided democracy.

Abstrak: Artikel ini memaparkan tentang perkembangan politik Islam di Indonesia dari pasca kemerdekaan hingga masa demokrasi terpimpin. Pada masa awal kemerdekaan, terjadi perdebatan di kalangan tokoh Islam dan nasionalis dalam merumuskan undang-undang, hingga disepakati adanya sila pertama yang berbunyi Ketuhanan yang Maha Esa. Pada masa demokrasi parlementer, banyak organisasi Islam yang mendirikan partai politik dan turut serta dalam Pemilu tahun 1955 diantaranya Masyumi, NU, PSII, dan Perti. Pada masa demokrasi terpimpin, ada dua kelompok partai Islam saat itu. Kelompok pertama Masyumi yang memandang keikutsertaan dalam sistem politik otoriter 
sebagai penyimpangan dari ajaran Islam. Kelompok kedua, yakni liga Muslim (NU, PSII, dan Perti), berpandangan bahwa turut serta dalam demokrasi terpimpin adalah sikap realistis dan pragmatis. Kehancuran Demokrasi Terpimpin terjadi setelah pemberontakan yang dilakukan oleh gerakan PKI 30 September 1965. Dengan berakhirnya masa Demokrasi Terpimpin maka berakhir pula masa orde lama dan berganti menjadi masa orde baru di bawah pimpinan Suharto. Hal tersebut mengakibatkan perubahan dalam politik Islam di Indonesia.

Kata Kunci: Islam, pasca kemerdekaan, demokrasi terpimpin.

\section{Pendahuluan}

Setelah berhasil menghancurkan kekuatan Belanda, Jepang akhirnya dikalahkan pada tahun 1945, maka terbukalah jalan bagi kemerdekaaan Indonesia. Tanggal 17 Agustus tahun 1945, Sukarno memproklamirkan kemerdekaan Indonesia. ${ }^{1}$ Kemerdekaan ini diraih melalui perjuangan kekuatan senjata, gerakan politik dan diplomatik serta kekuatan iman. ${ }^{2}$ Dengan bantuan Australia dan Inggris, Belanda berusaha merebut kembali kekuasaan atas wilayah Hindia; baru pada bulan Agustus 1950, dengan perlawanan dari pasukan tentara Indonesia dan tekanan dari Perserikatan Bangsa-Bangsa (PBB) Belanda akhirnya dipaksa mengakui kemerdekaan Republik Indonesia. ${ }^{3}$

Pada era pasca kemerdekaan, muncul beberapa wajah politik Islam. Pada tingkat partai, dua organisasi politik utama berupaya mendominasi mayoritas Muslim di republik baru ini; kedua kelompok itu mencerminkan keterbagian historis kaum Muslim. NU mendukung pandangan nonmodernis yang lebih tradisional, dan Masyumi berdiri sebagai partai Islam yang modernis. Mereka berlomba memimpin orang Indonesia yang berminat pada pemerintahan yang didasarkan atas nilai-nilai Islam, dan sangat menentang pengaruh sekuler dan khususnya komunis. ${ }^{4}$

' Ira. M. Lapidus, Sejarah Sosial Umat Islam bagian III, (Jakarta: PT RajaGrafindo Persada, 2000), 339.

2 Dede Rosyada, Hukum Islam dan Pranata Sosial, (Jakarta: PT RajaGrafindo Persada, 1999), 190.

${ }^{3}$ Ira. M. Lapidus, Sejarah Sosial Umat Islam bagian, 339.

${ }^{4}$ Ibid. 
Dalam makalah ini penulis akan menjabarkan tentang Islam di Indonesia dari masa kemerdekaan hingga Demokrasi Terpimpin.

\section{Politik Islam di Indonesia pada Masa Revolusi (1945-1949)}

Ketika Jepang semakin terdesak dalam perang Pasifik, perdana menteri Kiniaki Kaiso di depan resepsi Ulimereo Diet (parlemen) yang ke-85 tanggal 7 September 1944 menjanjikan kemerdekaan kepada Indonesia dalam waktu yang dekat. Sebagai realisasinya pada tanggal 9 April 1945 dibentuk Badan Penyelidik Usaha-Usaha Persiapan Kemerdekaan (BPUPKI). BPUPKI terdiri atas 38 orang anggota, yang terdiri dari 8 orang Jepang dan 15 orang dari golongan Islam, ${ }^{5}$ dan selebihnya dari golongan nasionalis sekuler dan priyayi Jawa.

Tugas BPUPKI adalah merumuskan bentuk negara, batasan negara, dasar filsafat negara, dan masalah-masalah lain yang perlu dimasukkan dalam konstitusi. ${ }^{6}$ Dalam sidang-sidangnya BPUPKI mengalami berbagai perdebatan ideologis yang sengit antara golongan Islam dengan golongan nasional sekuler tentang dasardasar negara yang akan diberlakukan di negara yang akan berdiri. Sebenarnya yang diperjuangkan oleh para tokoh Islam bukanlah realisasi negara Islam, tetapi lebih tepat pada adanya jaminan terhadap pelaksanaan syariat ajaran-ajaran Islam. Sedangkan golongan nasionalis yang dipelopori Sukarno dan Muhammad

5 Menurut Abdul Aziz Thaba, yang dimaksud golongan Islam adalah golongan yang memperjuangkan Islam sebagai dasar negara dalam sidang-sidang BPUPKI. Ini bukan berarti mereka tidak naionalis, begitu pula dengan golongan sekuler, bukan berarti mereka anti agama tetapi perbedaan mereka dilihat dari aspirasinya tentang dasar negara. Di antara I 5 orang wakil Islam itu adalah Abikusno Tjokrosujuso (bekas PSSI), KH Ahmad Sanusi (PUI Sukabumi), Ki Bagus Hadikusumo (Muhammadiyah), KH Masykur (NU) Abdul Kahar Mudzakir (Muhammadiyah), dll. Abdul Aziz Thaba, Islam dan Negara dalam Politik Orde Baru ,(Jakarta: Gema Insani Press, 1996), I53-I 54.

${ }^{6}$ Ahmad Syafi'i Ma'arif, Islam dan Politik, Teori Belah Bambu Masa Demkrasi Terpimpin, (Jakarta: Gema Insani Press, 1996). 
Hatta menghendaki negara persatuan nasional yang memisahkan urusan negara dan urusan Islam. ${ }^{7}$

Untuk meredam perpecahan, akhirnya disepakati untuk membentuk "Panitia Sembilan" yang terdiri dari lima orang dari golongan sekuler, yaitu Sukarno, Muhammad Hatta, Achmad Subarjo, Muhammad Yamin dan A.A Maramis. Sedangkan golongan Islam diwakili oleh H. Agus Salim, Kiai Wahid Hasyim, Abikusno, dan Abdul Kahar Mudzakir. ${ }^{8}$

Setelah bergumul selama lebih kurang 21 hari, akhirnya pada 22 Juni 1945 suatu sintesis dan kompromi politik dapat diwujudkan antara dua pola pemikiran yang berbeda. Sintesis inilah yang kemudian dikenal dengan Piagam Jakarta. Dalam piagam ini terdapat anak kalimat pengiring pada sila pertama: "dengan kewajiban menjalankan syariat Islam bagi pemelukpemeluknya."

Pada waktu proklamasi tanggal 17 Agustus 1945, Piagam Jakarta sama sekali tidak digunakan. Sukarno-Hatta justru membuat teks proklamasi yang lebih singkat karena ditulis dengan tergesa-gesa. ${ }^{10}$ Kompromi politik dalam bentuk Piagam Jakarta rupanya hanya mampu bertahan selama 57 hari. Anak kalimat pengiring yang terdiri dari tujuh atau delapan perkataan tersebut dirasakan oleh sebagian bangsa kita di belahan Timur sebagai diskriminatif terhadap pemeluk agama lain.

Perlu diketahui, menjelang kemerdekaan, setelah Jepang tidak dapat menghindari kekalahan dari tentara sekutu, BPUPKI ditingkatkan menjadi Panitia Persiapan Kemerdekaan Indonesia (PPKI). Berbeda dengan BPUPKI yang khusus untuk pulau Jawa, PPKI merupakan perwakilan daerah seluruh kepulauan Indonesia.

\footnotetext{
7 Kemerdekaan Indonesia pada dasarnya tidak bisa lepas dari tuntutan umat Islam, mereka berjuang dengan darah dan harta demi mencapai kemerdekaan Indonesia, Karen aitu wajar bila mereka menghendaki Indonesia merdeka itu sebagai negara Islam. M. Ali Haidar, Nahdlatul Ulama dan Islam di Indonesia, (Jakarta: PT Gramedia, 1998), 239-256.

${ }^{8}$ Ibid, 29.

${ }^{9}$ lbid.

${ }^{10}$ Badri Yatim, Sejarah Peradaban Islam, (Jakarta: PT RajaGrafindo Persada, 2002), 265.
} 
Perubahan itu menyebabkan banyak anggota BPUPKI yang tidak muncul lagi, ${ }^{11}$ termasuk beberapa orang anggota Panitia Sembilan.

Dalam suasana seperti itu, M. Hatta dalam sidang PPKI setelah kemerdekaan berhasil dengan mudah meyakinkan anggota bahwa hanya suatu konstitusi "sekuler" yang mempunyai peluang untuk diterima oleh mayoritas rakyat Indonesia. Maka demi persatuan bangsa, akhirnya anak kalimat itu pada tanggal 18 agustus 1945 dibuang dari pembukaan UUD 1945.12 Tujuh kata dalam anak kalimat yang tercantum dalam sila pertama Pancasila dengan segala konsekuensinya dihapuskan dari konstitusi. Bahkan kantor urusan agama seperti yang diperoleh Islam selam pendudukan Jepang, oleh panitia pun ditolak. ${ }^{13}$

Oleh golongan nasionalis "sekuler" keputusan itu dianggap sebagai gentleman's agrement kedua yang menghapuskan Piagam Jakarta sebagai gentleman's agrement pertama. Sementara itu, keputusan yang sama dipandang oleh golongan nasionalis Islam sebagai mengkhianati gentleman's agrement itu sendiri. Para nasionalis Islam mengetahui bahwa Indonesia Merdeka yang mereka perjuangkan dengan penuh perngorbanan itu, jangankan berdasarkan Islam, Piagam Jakarta pun tidak. Hal tersebut menyebabkan kekecewaan yang luar biasa bagi para nasionalis Islam.

\footnotetext{
' Anggota sidang PPKI saat itu adalah 27 orang, namun hanya tiga anggota yang berasal dari organisasi Islam, yaitu Ki Bagus Hadikusumo, KH. A. Wahid Hasyim dan Kasman Singodimejo. Lihat Ahmad Syafi' Maarif, Islam dan Politik, Teori Belah Bambu Masa Demokrasi Terpimpin, 29.

${ }^{12}$ Alasan penerimaan perubahan Piagam Jakarta ini dari golongan Islam ini dikemukakan oleh Abdul Aziz Thaba ada tiga: pertama, golongan Islam yang menerima penghapusan tujuh kata tersebut atas lobbi M. Hatta dalam pembicaraan mereka pada pagi harinya tanggal 18 Agustus 1945.lagipula kata ketuhanan ditambahkan dengan "Yang Mahan Esa" menurut interpretasi golongan Islam tentang kalimat itu adalah nama lain dari tauhid dalam Islam, sebab Islam lah yang mengenal keesaan Tuhan (tauhid). Kedua, suhu politik sehari setelah proklamasi, terutama di Jakarta, sangat tinggi, maka tidak harus mengalami perdebatan-perdebatan yang mengancam persatuan bangsa. Ketiga, golonggan Islam berharap setelah enam bulan setelah proklamasi akan diadakan pemilihan umum dimana mereka akan ikut serta dan yakin akan memenangkannya mengingat jumlah penduduk Indonesia yang mayoritas beragama Islam. Ibid, 157.

13 Badri Yatim, Sejarah Peradaban Islam, 265.
}

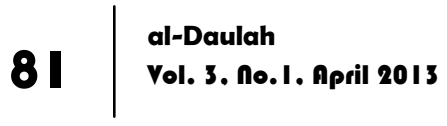


Yang sedikit agak melegakan hati umat Islam adalah keputusan Komite Nasional Islam Pusat (KNIP), pengganti PPKI, yang bersidang tanggal 25, 26, dan 27 November 1945. Komite yang dipimpin oleh Sutan Syahir, pimpinan utama Partai Sosialis Indonesia (PSI) itu antara lain membahas usul agar dalam Indonesia merdeka ini soal-soal keagamaan digarap oleh satu kementrian tersendiri dan tidak lagi diperlakukan sebagai bagian tangung jawab Kementerian Pendidikan. Sedikit banyak keputusan tentang kementerian Agama ini merupakan semacam konsesi kepada kaum muslimin yang bersifat kompromi; kompromi antara teori sekuler dan teori muslim. ${ }^{14}$

Meskipun Departemen Agama dibentuk, namun hal itu tidak meredakan konflik ideologi pada masa sesudahnya. Di beberapa wilayah pinggiran, beberapa kelompok Muslim menolak sikap kompromi ini dan bersikeras untuk bertempur demi merealisasikan sebuah negara Islam. Di antara gerakan pemberontakan Islam yang terbesar adalah Dâr al-Islam, yang didirikan oleh mantan aktivis Sarekat Islam bernama Kartosuwiryo. Ia berperang melawan Belanda pada tahun 1947 dan pada tahun 1948 ia tidak mau menerima perjanjian Renville antara Indonesia dan Belanda, keluar dari partai Masyumi, bertahan untuk melanjutkan pertempuran militer dengan caranya sendiri, dan menyatakan dirinya sebagai imam untuk sebuah pemerintahan Islam sementara, Negara Islam Indonesia. Negara Islam ini ditegaskan sebagai negara yang berdasarkan al-Qur'an dan hadis, dan sebuah republik konstitusi dengan sebuah parlemen hasil pemilihan. Sang imam, yang dipilih oleh parlemen, merupakan kepala negara. Negara baru tersebut menegaskan bahwasanya negara memberikan perlindungan yang sama di muka hukum, hak standar kehidupan yang tinggi, dan kebebasan beribadah, berbicara, dan perwakilan untuk seluruh warga. Pertempuran militer melawan Belanda dan belakangan melawan

${ }^{14} \mathrm{Ibid}, 266$. 
Republik Indonesia terus berlangsung hingga gerakan ini akhirnya dibasmi pada tahun $1962 .{ }^{15}$

Setelah wakil Presiden mengeluarkan maklumat no.x tentang diperkenankannya mendirikan partai-partai politik, tiga kekuatan yang sebelumnya bertikai muncul kembali. Pada tanggal 7 November 1945 Majelis Syura Muslimin Indonesia (Masyumi) lahir sebagai wadah aspirasi umat Islam, 17 Desember 1945 Partai Sosialis yang mengkristalisasikan falsafah hidup Markis berdiri, dan 29 Januari 1946, Partai Nasional Indonesia (PNI) yang mewadahi cara hidup nasionalis "sekuler" pun muncul. Partaipartai yang berdiri sesudah itu dapat dikategorikan ke dalam tiga aliran utama ideologi yang terdapat di Indonesia di atas. Partaipartai Islam setelah merdeka selain Masyumi adalah Partai Sarikat Islam Indonesia (PSII) yang keluar dari Masyumi tahun 1947, Persatuan Tarbiyah Islamiyah (Perti), dan Nahdlatul Ulama (NU) yang keluar dari Masyumi tahun 1952. ${ }^{16}$

Dalam masa-masa revolusi, konflik ideologi di atas memunculkan tiga alternatif dasar negara: Islam, Pancasila, dan Sosial Ekonomi. Tetapi, dalam perjalanan sidang-sidang konstituante itu, perdebatan ideologis mengenai unsur dasar negara terkristal menjadi Islam dan Pancasila. ${ }^{17}$

\section{Politik Islam di Indonesia Masa Demokrasi Parlementer (1949- 1959)}

Setelah penyerahan kedaulatan 27 Desember 1949, sejarah politik Indonesia memasuki babak baru dengan diterapkannya sistem demokrasi parlementer dan konstitusi UUD RIS 1949 yang kemudian diganti dengan UUDS 1950. Pada tahun 1950-1957 ditandai dengan jatuh bangunnya partai-partai politik yang berumur rata-rata kurang dari setahun. Setelah NU keluar dari Masyumi, parpol Islam diwakili oleh Masyumi, NU, PSII, dan

\footnotetext{
${ }^{15}$ Ira M Lapidus, Sejarah Sosial Umat Islam bagian III, 339.

${ }^{16}$ Badri Yatim, Sejarah Peradaban Islam, 267.

${ }^{17}$ Ibid.
} 
Perti. Ciri lainnya tidak satu pun parpol yang mayoritas. Pada masa revolusi, PNI dan Masyumi sering mengadakan kerjasama, namun pada masa ini hubungannya tidak serasi lagi, bahkan dalam saat-saat tertentu sama sekali terputus.

Peranan partai politik Islam dalam kabinet-kabinet pada kurun waktu itu mengalami pasang surut, seiring dengan jatuh bangunnya kabinet. Dalam kabinet Hatta (1950), Masyumi memperoleh jatah empat kursi menteri. PSII dan Perti tidak masuk. Sedang dalam kabinet Natsir (1950-1951), yang merupakan kabinet pertama yang dipimpin oleh Masyumi, duduk 4 orang dari Masyumi dan 2 dari PSII. Dalam kabinet Sukiman (1951-1952) yang merupakan koalisi Masyumi dan PNI, kedua belah pihak memeperoleh jatah lima kursi, sedangkan PSII dan Perti tidak disertakan. Berikutnya, dalam kabinet Wilopo (1952-1953), Masyumi mendapat jatah 4 kursi, termasuk menteri agama (Fakih Utsman dari Muhammadiyah). Wilopo (PNI) ditunjuk setelah Prawoto (Masyumi) dan Sidik (PNI) gagal membentuk kabinet. Kabinet Ali Sastroamijoyo I (1953-1955) mengikut sertakan wakil $\mathrm{NU}$ atas nama organisasinya, ikut dalam pemerintahan. Kabinet Ali I jatuh, dan digantikan oleh kabinet Burhanuddin Harahap (1955-1956) dari Masyumi dengan tugas khusus menyelenggarakan pemilu 1955. Setelah hasil PEMILU tahun 1955 ini secara resmi kabinet Burhanuddin bubar. ${ }^{18}$

Pemilu 1955 menghasilkan empat partai besar, yaitu PNI, Masyumi, NU, dan PKI. Tidak ada yang menang mayoritas. PNI urutan pertama denagn 22,3\% suara, Masyumi 20,9\% suara, NU $18,4 \%$, sedangkan sisa terbagi di antara partai-partai kecil lainnya.

\section{Politik Islam di Indonesia Masa Demokrasi Terpimpin (1959- 1965)}

Usaha partai-partai Islam untuk menegakkan Islam sebagai ideologi negara di dalam konstituante mengalami jalan buntu. 
Demikian juga dengan Pancasila, yang oleh umat Islam waktu itu, dipandang sebagai milik kaum "anti Islam" ;setidak-tidaknya di dalam konstituante. Memang kesempatan untuk menyelesaikan tugas konstituante masih terluang, namun pekerjaannya diakhiri dengan Dekrit Presiden 1959, konstituante dinyatakan bubar dan UUD 1945 dinyatakan berlaku kembali. Dalam konsideran Dekrit itu disebutkan bahwa Piagam Jakarta menjiwai dan merupakan suatu rangkaian kesatuan dengan UUD 1945. Jelas, Dekrit sebenarnya ingin mengambil jalan tengah. Tapi dekrit itu sendiri menandai bermulanya sutau era baru, Demokrasi Terpimpin, 19 yang sebelumnya, Bung Karno dalam berbagai kesempatan, mencela pemerintahan banyak partai. Baginya sistem parlementer tidak sesuai dengan alam pikiran Indonesia. Oleh karena itu, sistem ini harus diganti dengan sistem politik lain yaitu demokrasi terpimpin. Sejak tahun 1957 Sukarno sudah berusaha melancarkan sistem parlementer dengan menciptakan sebuah sistem "Demokrasi Terpimpin", ia merancang pembentukan sebuah kabinet termasuk di dalamnya dewan komunis dan nasionalis untuk mewakili kepentingan kelompok pekerja, petani, pemuda, dan kelompok regional. Pergantian kekuasaan ini menjadikan pengaruh Komunis tersebar luas, membangkitkan kekhawatiran keinginan pihak Muslim atas otonomi regional. Para pemuka militer di Sumatera dan Sulawesi dan tokoh-tokoh juru bicara Muslim yang mewakili partai Masyumi, termasuk Muhammad Natsir, pimpinan partai ini, menentang rencana tersebut dan membentuk sebuah pemerintahan revolusioner Republik Indonesia. Pemerintahan revolusioner tersebut kalah, dan pada bulan Juli 1959 Sukarno membubarkan majelis konstituante dan mengumumkan pernyataan kembali kepada Undang-Undang Dasar 1945.20 Seminggu setelah dekrit 5 Juli 1959, Sukarno mengumumkan kabinetnya yang baru, menggantikan Kabinet

\footnotetext{
${ }^{19}$ Badri Yatim, Sejarah Peradaban Islam, 268.

${ }^{20}$ Ira M. Lapidus, Sejarah Sosial Umat Islam bagian III, 339.
}

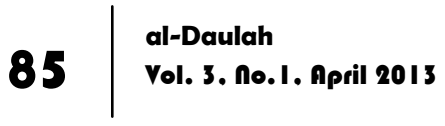


Juanda. Kabinet Juanda adalah kabinet peralihan dari periode Demokrasi Parlementer ke Demokrasi Terpimpin.

Demokrasi gaya baru ini memang sudah lama ia dambakan, tapi karena posisinya tidak kokoh, sistem inilah yang membawanya kepada kehancuran untuk selamanya. Lebih jauh ia mengantarkan negeri ini kepada kehancuran ekonomi sebagai akibat dari pengeluaran yang sangat besar dan akumulasi hutang asing yang membengkak.

Demokrasi terpimpin ini membawa kehidupan demokratis terancam dan berada dalam krisis. Masyumi yang sangat ketat berpegang kepada konstitusi, yang selalu melancarkan kritik tajam dianggap sebagai perintang revolusi pada bulan Agustus 1960 diperintahkan presiden Sukarno bubar. ${ }^{21}$ Sedangkan NU dan Perti tetap diizinkan untuk eksis dalam setiap pemilu, karena mereka mendukung Demokrasi terpimpin.

Sementara itu, organisasi anggota Masyumi seperti Muhammadiyah, Mathla'ul Anwar, al-Ittuhadiyah, al-Jami'ah alWashliyah, al-Irsyad, dan Persatuan Islam (Persis), sebelum Masyumi dibubarkan, dengan penuh pengertian kedua belah pihak, mengundurkan diri dari partai.

Jadi, secara garis besar, ada dua kelompok partai Islam saat itu. Kelompok pertama Masyumi yang memandang keikutsertaan dalam sistem politik otoriter sebagai penyimpangan dari ajaran Islam. Kelompok kedua, yakni liga Muslim (NU, PSII, dan Perti), berpandangan bahwa turut serta dalam demokrasi terpimpin adalah sikap realistis dan pragmatis.

Di mata Masyumi sistem Demokrasi Terpimpin akan membawa kehancuran bagi bangsa dan negara. Karena itu Sukarno harus dilawan, apapun akibatnya. Memang Masyumi tidak mempunyai pilihan lain kecuali menghadapi Sukarno dan sistemnya, sekalipun dengan sisa-sisa tenaga yang tidak seimbang.

${ }^{21}$ Badri Yatim, Sejarah Peradaban Islam, 268. 
Harapan Masyumi bahwa rakyat akan memihak demokrasi, tidak kepada sistem otoriter, ternyata sia-sia.

Dengan dibubarkannya Masyumi, NU menjadi parpol Islam terbesar, tetapi sebenarnya, pengaruhnya dalam proses pengambilan kebijaksanaan nasional sangat kecil, atau bahkan tidak ada sama sekali.

Di masa Demokrasi Terpimpin ini, Sukarno kembali menyuarakan ide lamanya NASAKOM, suatu pemikiran yang ingin menyatukan nasionalis sekuler, Islam dan komunis. Akan tetapi, idenya itu dilaksanakan dengan caranya sendiri. Peranan partai mengalami erosi, kecuali PKI yang memainkan peranan penting dan diliputi dengan semangat yang tinggi. Pancasila pun ditafsirkan sesuai dengan pemikirannya. Masa ini, karena lebih didominasi oleh PKI yang memainkan peranan penting dan diliputi dengan semangat yang tinggi. Pancasila pun ditafsirkan sesuai dengan pemikirannya. Masa ini, karena lebih didominasi oleh PKI, memendam ketegangan antara Islam dan komunisme. Ketidakpuasan juga terjadi di kalangan banyak golongan nasionalis "sekuler" dan angkatan bersenjata. ${ }^{22}$

Menurut analisis sebagian pakar, sikap akomodatif NU terhadap pemerintahan Sukarno adalah sebagai usaha menandingi dan menentang PKI dalam semua aspek kehidupan. Dalam bidang kepemudaan PKI membentuk Gerakan Ofensip Pemuda, NU menandingi dengan Banser Ansor, dalam bidang perburuan PKI membentuk SOBSI, NU membentuk Sarbumusi (Sarikat Buruh Muslim Indonesia). Dalam bidang pertanian, PKI membentuk BTI (Barisan Tani Indonesia), NU menandinginya dengan Pertanu (Persatuan Tani NU). Dalam bidang kebudayaan PKI menggalang LEKRA (Lemaga Kebudayan Rakyat), NU menandinginya dengan Lesbumi (Lembaga Seni Budaya Muslim). Selain organisasi di atas, NU juga membentuk organisasi tertentu untuk menggalang massa, seperti IPPNU (Ikatan Pelajar Pelaar NU), Muslimat Nahdlatul 
Ulama, HPMI (Himpunan Pengusaha Muslim Indonesia), ISSI (Ikatan Sarjana Islam Indonesia), dll.

Kehancuran Demokrasi Terpimpin terjadi setelah pemberontakan yang dilakukan oleh gerakan PKI 30 September 1965. Umat Islam bersama ABRI dan golongan lainnya bekerjasama menumpas gerakan itu. ${ }^{23}$ Berpegang pada selembar surat perintah tangal 11 Maret 1966 (Supersemar), jenderal Suharto, pemegang mandat, mengambil langkah-langkah untuk menyelamatkan negara. Terhitung sejak tanggal tersebut dibangun sebuah "orde baru" pengganti "orde Lama". ${ }^{24}$

\section{Beberapa Lembaga Islam di Indonesia Pasca Kemerdekaan}

Di bawah ini dijelaskan perkembangan beberapa lembaga Islam setelah Indonesia merdeka di antaranya Departemen Agama, lembaga pendidikan, lembaga hukum Islam, dan lembaga haji.

\section{Departemen Agama}

Departemen Agama (sekarang namanya Kementrian Agama) didirikan pada masa kabinet Syahrir yang mengambil keputusan tanggal 3 januari 1946 untuk memberikan sebuah konsesi kepada kaum muslimin. Menteri agama pertama adalah M. Rasyidi yang diangkat pada tanggal 12 Maret 1946. Usaha untuk mendirikan departemen itu mulanya mendapat halangan dari para perumus UUD 1945, ketika PPKI mengadakan rapat tangggal 19 Agustus 1945. Akan tetapi, Komite Nasional Indonesia Pusat (KNIP), pada tanggal 11 November 1945 mengusulkan pendiriannya. Usul itu diprakarsai oleh K.H Abu Dardiri, K.H. Saleh Su'aidi, dan M. Sukoso Wirjosaputro, kesemuanya adalah anggota KNIP dari daerah Abnyumas. Usul itu mendapat dukungan dari $\mathrm{M}$. Natsir, Dr. Muwardi, Dr. Marzuki Mahdi, dan M. Kartosudarmo (semuanya anggota KNIP) dan disetujui oleh 
badan legisatif tersebut. Dapat dikatakan bahwa berdirinya Departemen Agama merupakan penyesuaian pihak pemerintah kala itu dengan keinginan mayoritas muslim.

Sebelum terbentuknya kementerian ini, ada pembahasan mengenai apakah kementerian ini akan dinamakan Kementerian Agama Islam ataukah Kementerian Agama. Akhirnya diputuskan menjadi Kementerian Agama, yang pertama-tama mempunyai tiga seksi dan kemudian empat seksi. Masing-masing untuk kaum muslimin, umat Protestan, umat Katolik Roma, dan umat Hindu-Budha. Karena ia tidak mengatur hanya satu agama, tetapi lima agama yang diakui di Indonesia, maka pemimpin politik Indonesia mengatakan bahwa Indonesia bukanlah negara "sekuler" dan bukan juga negara agama. Dasar pertama dari Pancasila adalah "Ketuhanan Yagn Maha Esa", dianggap memadai untuk membenarkan adanya Departeman Agama. ${ }^{25}$

Tujuan dan fungsi Departemen Agama yang dirumuskan pada tahun 1967 adalah sebagai berikut:

a. Mengurus serta mengatur pendidikan agama di sekolahsekolah, serta membimbing perguruan-perguruan agama.

b. Mengikuti dan memperhatikan hal yang bersangkutan dengan agama dan keagamaan.

c. Memberi penerangan dan penyuluhan agama

d. Mengurus dan mengatur peradilan agama serta menyelesaikan masalah yang berhubungan dengan hukum agama.

e. Mengurus dan memperkembangkan IAIN, perguruan tinggi agama swasta dan pesantren luhur, serta mengurus dan mengawasi pendidikan agama pada perguruanperguruan tinggi.

f. Mengatur, mengurus, dan mengawasi penyelenggaraan ibadah haji.

${ }^{25}$ Badri Yatim, Sejarah Peradaban Islam, 307. 


\section{Pendidikan}

Dalam bidang pendidikan Islam, Indonesia selalu mendapat sorotan atau perhatian, karena memiliki penduduk Islam terbesar di dunia. Lembaga Pendidikan Tinggi Islam yang pertama di Indonesia adalah IMS Solo tahun 1939 dan pada tahun 1940 menyusul Jakarta, namun setelah Sekolah Tinggi Islam Jakarta dipindah ke Yogyakata namanya diubah menjadi Universitas Islam Indonesia.

Sejak tahun 1960-an , pengetahuan Islam telah masuk ke dalam kurikulum sekolah-sekolah dan universitas-universitas negeri. Selama bertahun-tahun Indonesia menonjol dalam penerbitan literature pendidikan Islam, bahkan pasokan bukubuku Islam di Malaysia dan Singapura didominsai dari Indonesia. Selain itu para ahli agama juga sangat memperhatikan peran pondok pesantren sebagai suatu agen perubahan yang dinamis. ${ }^{26}$

Setelah Indonesia merdeka, terutama setelah berdirinya Departemen Agama, persoalan pendidikan agama Islam mulai mendapat perhatian lebih serius. Badan Pekerja Komite Nasional Pusat dalam bulan Desember 1945 menganjurkan agar pendidikan madrasah diteruskan. Badan ini juga mendesak pemerintah agar memberikan bantuan kepada madrasah. Departemen Agama dengan segera membentuk seksi khusus yang bertugas menyusun pelajaran dan pendidikan agama Islam dan Kristen, mengawasi pengangkatan guru-guru agama, dan mengawasi pendidikan agama. Pada tahun 1946, Departemen agama mengadakan pelatihan 90 guru agama, 45 orang di antaranya kemudian diangkat sebagai guru agama. Pada tahun 1948, didirikanlah sekolah guru dan hakim Islam di Solo.

${ }^{26}$ Maryam Jamilah, dkk, Sejarah Perdaban Islam dari masa Klasik hingga Modern, (yogyakarta: Lesfi, 2002), 4I 5. 
Haji Mahmud Yunus, seorang alumni Kairo yang di zaman Belanda memimpin Sekolah Normal Islam di Padang, menyusun rencana pembangunan pendidikan Islam. Ketika itu ia mengepalai seksi Islam dari kantor Agama Propinsi. Dalam rencananya, ibtidaiyah selama 6 tahun, tsanawiyah pertama 4 tahun dan tsanawiyah atas 4 tahun. Gagasannya ini dilaksanakan di Lampung tahun 1948. Sementara itu Aceh, meleksanakan gagasannya sendiri. Banyak sekolah-sekolah swasta di daerah ini dijadikan sekolah negeri, sekurangkurangnya memperoleh subsidi dari pemerintah. Mahmud Yunus juga menyarankan agar pelajaran agama diberikan di selkolah-sekolah "umum" yang disetujui oleh konperensi pendidikan se-Sumatera di Padang Panjang, 2-10 Maret 1947.27

Bentuk-bentuk lemabaga pendidikan Islam swasta adalah: pertama, Pesantren Indonesia Klasik. Kedua, Madrasah diniyah (sekolah agama), yaitu sekolah-sekolah yang memberikan pelajaran tambahan bagi murid sekolah negeri yang berusia 7-20 tahun. Ketiga, madrasah-madrasah swasta, biasanya mata pelajaran dan sistem pengajaran sama dengan sekolah negeri ${ }^{28}$

Berkenaan dengan Perguruan Tinggi Islam, kaum muslimin di Indonesia sejak awal sudah berpikir untuk membangunnya. Mahmud Yunus membuka islmaic College pertama tanggal 9 Desember 1940 di Padang, yang terdiri dari fakultas Syariah dan fakultas Pemdidikan dan Bahasa Arab. Tujuannnya adalah untuk mendidik ulama.

Universitas Islam Indonesia (UII) adalah perguruan tinggi Islam pertama yang memilki fakultas-fakultas non-agama. IA bermula di awal tahun 1945, di saat Masyumi memutuskan untuk mendirikan Sekolah Tinggi Islam di Jakarta. Dengan bantuan dari pemerintah pendudukan Jepang, lembaga ini dibuka pada tanggal 8 juli 1945 di Jakarta. Tidak lama setelah

${ }^{27}$ Badri Yatim, Sejarah Peradaban Islam, 310.

28 Ibid, 3 | I. 
itu, lembaga ini ditutup karena gedung-gedung dikuasai oleh pasukan sekutu, dan dibuka kembali tanggal 10 April 1946 di Yoigyakarta. Pada tanggal 22 Januari 1950 sejumlah pemimpin Islam mendirikan sebuah universitas Islam di Solo,dan 20 Februari 1951 kedua universitas Islanm di Yogyakarta dan di Solo itu disatukan dengan nama Universitas Islam Indonesia (UII) yang sejak itu mempunyai cabang di dua kota tersebut. Setelah itu, mulai banyak muncul perguruan tinggi dan universitas Islam.

\section{Hukum Islam}

Pengadilan Islam di Indonesia membatasi dirinya pada soal-soal hukum muamalat yang bersifat pribadi. Hukum muamalat pun terbatas pada masalah nikah, cerai, dan rujuk; hukum waris (faraidl), wakaf, hibah, dan baitul mal.

Keberadaan lembaga peradilan agaam di masa Indonesia merdeka dalah kelanjutan dari masa kolonial Belanda. Pada masa pendudukan Jepang, pengadilan agama tidak mengalami perubahan. Setelah Indonesia merdeka jumlah pengadilan agama bertambah, tetapi administrasinya tidak segera diperbaiki. Para hakim Islam nampak ketat dan kaku karena hanya berpegang apda madzhab Syafi'i. Sementara itu, belum ada kitab undang-undang yang seragam yang dapat dijadikan pegangan para hakim dan pengadilan Agaama didominasi oleh golonbgan tradisionalis. Karena itulah, sekolah Pendidikan Hakim Islam Negeri (PHIN) dan Fakultas Syari'ah di perguruan-perguruan tinggi Islam didirikan. ${ }^{29}$

\section{Haji}

Semenjak zaman penjajahan Belanda, umat Islam Indonesia ingin mempunyai kapal laut untuk dipergunakan dalam penyelenggaraan perjalanan haji iuran dikumpulkan, 
saham diedarkan, tetapi selama zaman jajahan keinginan ini tidak terwujud. Setelah indonesia Merdeka, usaha ini dilanjutkan. Pada tahun 1950 sebuah yayasan, yaitu Yayasan Perjalanan Haji Indonesia, didirikan di Jakarta.

Pemerintah memberikan kuasa kepada Yayasan itu untuk menyelenggarakan perjalanan haji. Sebuah bank, Bank Haji Indonesia, dan sebuah perusahaan kapal, Pelayaran Muslimin Indonesia (MUSI) didirikan. Tetapi sepuluh tahun kemudian perusahaan MUSI ini masih saja bertindak sebagai agen dalam mencarter kapal dari perusahaan asing; MUSI tidak mmepunyai kapal sendiri. Cara ini ditempuh hingga tahun 1962, Petugas MUSI dibekukan oleh pemerintah, mungkin sekali karena pertimbangan politik. Setahun sebelumnya, pada tahun 1961, Petugas Haji Indonesia (PHI) yang bertugas memberikan kemudahan-kemudahan naik haji, juga dibubarkan karena banyak anggota PHI adalah anggota Masyumi, partai yangtelah dibubarkan.

Dalam tahun 1961 itu juga suatu perusahaan pelayaran baru, Perseroan Terbatas "Arafat" didirikan, dengan modal yang berasal dari pada jemaah haji atau calon jemaah itu sendiri. Selanjutnya, pada tahun 1964 hingga jatuhnya resim Sukarno, panitia perbaikan haji diganti dengan badan baru, Dewan Urusan Haji. Dewan ini mengajak PHI untuk kembali mengurus jemah haji, tetapi campur tangan pemerintah di dalamnya semakin besar karena tanggungjawab penyelenggaraan haji terletak pada pemerintah setempat. Namun, semua usaha yang dilakukan itu tidak ada yang berhasil baik.

\section{Penutup}

Indonesia, yang merdeka pada tanggal 17 Agustus 1945, sekalipun mayoritas masyarakatnya muslim, menyatakan diri sebagai negara yang berdasarkan Pancasila. Demokrasi Terpimpin yang diterapkan hanya meningkatkan suhu konflik antara etnis, 
agama, dan ideologi di antara rakyat Indonesia. Partisipasi politik hanya melahirkan harapan-harapan masyarakat yang tidak realistis, yang pada akhirnya menimbulkan perpecahan di kalangan kaum muslimin. Awalnya Islam hanya digunakan untuk mendukung partai politik Islam seperti NU atau Masyumi, namun di waktu yang sama politisasi mengarah pada perpecahan antara partai Islam dan organisasi politik lainnya. Untuk mendamaikan di antara partai poliltik yang bertikai, Sukarno mencoba menerapkan Demokrasi Terpimpin dalam rangka menyiapkan persatuan nasional Indonesia yang dikenal dengan NASAKOM (Nasionalisme, agama, dan komunisme). Akan tetapi jalan yang satu ini gagal juga setelah komunis melakukan kudeta pada tahun 1965.

Dengan berakhirnya masa Demokrasi Terpimpin berakhir pula kepemimpinan Sukarno, dan pemerintahan "orde baru" di bawah presiden Suharto mulai berkuasa menggantikan "orde lama" tersebut.

\section{Daftar Pustaka}

Esposito, John L. Ensiklopedia Oxford Dunia Islam Modern. Bandung: Mizan, 2001.

Haidar, M. Ali. Nahdlatul Ulama dan Islam di Indonesia. Jakarta: PT Gramedia, 1998.

Lapidus, Ira. M. Sejarah Sosial Ummat Islam bagian ke III. Jakarta: PT RajaGRafindo Persada, 2000.

Ma'luf, Louis. al-Munjid. Beirut: Dar al-Masyriq, 2000.

Maarif, Ahmad Syafi'i. Islam dan Politik, Teori Belah Bambu Masa Demkrasi Terpimpin. Jakarta: Gema Insani Press, 1996.

Madjid, Nurcholish. Islam Kemodernan dan Keindonesiaan. Bandung: Mizan, 1992.

Maryam, Siti, dkk. Sejarah Peradaban Islam dari Masa Klasik hingga Modern. Yogyakarta: LESFI, 2002. 
Pulungan, J. Suyuthi. Figh Siyasah. Jakarta: PT RajaGrafindo Persada, 1999.

Rosyada, Dede. Hukum Islam dan Pranata Sosial. Jakarta: PT RajaGrafindo Persada, 1999.

Thaba, Abdul Aziz. Islam dan Negara dalam Politik Orde Baru. Jakarta: Gema Insani Press, 1996.

Yatim, Badri. Sejarah Peradaban Islam. Jakarta: PT RajaGrafindo Persada, 2002. 